\title{
THE RELATIONSHIPS OF PERCEPTION AND SIMPLICITY OF HEALTH SERVICE PROCEDURE WITH UTILIZATION OF THE INTEGRATED FAMILY HEALTH POST IN SOUTH TAPANULI, NORTH SUMATERA
}

\author{
Wilda Zulihartika Nasution, Destanul Aulia, Zulhaida
}

Masters Program in Public Health, Universitas Sumatera Utara

\begin{abstract}
Background: Integrating health services, such as family planning with HIV care or with maternal and child health care, can be more convenient for clients and more efficient for programs. Integrated services can be more efficient by avoiding duplication of effort and can serve more people at the same or similar cost by saving money that might have been spent maintaining separate facilities. This study aimed to determine the relationships of perception and simplicity of health service procedure with utilization of the integrated family health post in South Tapanuli, North Sumatera.

Subjects and Method: This was a cross-sectional study conducted at several posyandus (integrated family health posts), in the catchment area of Puskesmas (Community Health Center) Sayurmatinggi, Tapanuli Selatan, North Sumatera. A sample of 96 mothers who had children under-five years of age was selected for this study. The dependent variable was use of posyandu. The independent variables were perception about posyandu and service procedure. The data were collected by questionnaire and analyzed by a multiple logistic regression.

Results: Use of the integrated family health post was associated with its good perception $(\mathrm{OR}=3.22 ; 95 \% \mathrm{CI}=1.50$ to $4.99 ; \mathrm{p}=0.001)$ and simple service procedure $(\mathrm{OR}=4.13 ; 95 \% \mathrm{CI}=2.57$ to $6.67 ; \mathrm{p}=0.002)$.

Conclusion: Use of the integrated family health post increases with its good perception and simple service procedure.
\end{abstract}

Keywords: integrated family health post, utilization, perception, service procedure.

\section{Correspondence:}

Wilda Zulihartika Nasution. Masters Program in Public Health, Universitas Sumatera Utara, Jl. Dr. T. Mansur No. 9, Padang Bulan, Medan, North Sumatera. Email: zulihartika.wilda12@gmail.com. Mobile: 08527601980o 